\title{
CHARACTERISTICS OF SPIRITUAL AND SOCIAL VALUES IN SAMAN DANCE CULTURE IN GAYO COMMUNITY
}

\author{
Hardi Alunaza*1, Mentari ${ }^{2}$ \\ ${ }^{1}$ Faculty of Social and Political Science, Universitas Tanjungpura \\ ${ }^{2}$ Universitas Tanjungpura \\ Email: hardi.asd@fisip.untan.ac.id
}

\begin{abstract}
This research is going to explain the characteristics of spiritual and social values in saman dance culture in gayo community in Aceh. Saman Gayo dance is not only unique but also has original Indonesian cultural values which is one of the media for delivering da'wah messages which contains religious values, manners, togetherness, and educational values. This research on the characteristics of spiritual and social values in the Saman Dance culture in the Gayo community is a descriptive study with a qualitative approach. The data analysis technique in this paper refers to the data analysis technique of Miles and Huberman with three stages, namely data collection, data processing, and drawing conclusions. The data collection technique in this paper is to use data collection methods that are literature study to more accurately research from a scientific perspective. The results of this paper shown that the Gayo Saman Dance has various philosophies such as singing, movement, types of Saman Dance, to its function which of course must be maintained and preserved. In the other hand, Saman Dance is used to strengthen Local Identity, good values ranging from values in the field of education, unity and integrity, friendship.

Keyword : Saman Gayo Dance, Social Values, Spiritual Message, Gayo Culture
\end{abstract}

\section{INTRODUCTION}

Saman dance is a culture that is very close to the Gayo Lues community in Aceh. Saman dance is also known as a folk dance which has received recognition from UNESCO in 2011 ${ }^{1}$. Just like other cultures, Saman Gayo Dance also requires protection not only from the government as a stakeholder, but also all elements of Indonesian society. Because this Gayo Saman Dance is a form of identity for the Gayo community which is one of the media for delivering da'wah messages which contains religious values, manners, togetherness, and educational values ${ }^{2}$.

The Saman Gayo dance is one of the local wisdoms that has long been used as a medium for conveying information and messages of Islam as an element that must be owned by the

1 Alunaza, Hardi. Analisa Diplomasi Budaya Indonesia Melalui Tari Saman Gayo dalam Mengukuhkan Identitas Nasional Bangsa, Jurnal Hubungan Internasional, 2015. P: 88-96.

2 Yusnizal, Henywati. Tari Saman Pada Masyarakat Aceh; Identitas dan Akutalisasi, Laporan Disertasi Doktoral. Universitas Negeri Medan.

Al Qalam: Jurnal Ilmiah Keagamaan dan Kemasyarakatan Vol. 16, No. 1 Januari - Juni 2022 
Hardi Alunaza, Mentari : Characteristics Of Spiritual and Social Values in Saman Dance Culture In Gayo Community

Indonesian people to be able to become a unifier of the nation's life in the midst of diverse cultures with various differences ${ }^{3}$. Saman Gayo dance is not only unique but also has original Indonesian cultural values that must be preserved so as not to be claimed by other nations such as claims against Reog Ponorogo, Rasa Sayange Song, Batik, and Gondang Sambilan. This culture is also known as archipelago content that can bridge the world peace process in maintaining national identity.

The cultural diversity possessed by regions in Indonesia must of course be maintained so that it does not become a problem at the domestic level and also with other countries ${ }^{4}$. Given that with a variety of cultures, Indonesia can be recognized as a country with a very diverse culture. Apart from being a lure for foreign tourists to Indonesia, local cultural wisdom can also be used as a manifestation of the rich history of this motherland. The challenges of the national spirit and the diversity of life at the local level are again limited due to globalization. Globalization has become a spear and erodes the spirit of love for the homeland which makes many people lose their awareness that at certain point's local culture has a very strategic role to show the existence of a nation. Globalization is a threat of disintegration in the life of a society or nation which is marked by separation or division in the form of conflict or inequality ${ }^{5}$.

This paper is attempted to explain the characteristics of the spiritual values contained in the Saman Gayo Dance which must be preserved as part of Indonesia's wealth. Given that this Saman Dance not only contains an invitation to get closer to the creator, but also has a deep meaning for the education, socio-cultural sector, and also unity. The author assumes that this Gayo Saman Dance has various philosophies such as singing, movement, types of Saman Dance, to its function which of course must be maintained and preserved.

This paper is analyzed using the concept of national identity which certainly has a positive and good impact on the Indonesian people. So far, there have been many studies regarding the Saman Dance, such as what has been done by Yusnizar (2012) then Masyitah Ultari (2019), Ena Malikussaleh (2013), Alunaza (2015) and several writings on the variety and function of the Saman Dance. However, the researchers mentioned above do not clearly state what social and spiritual values are contained in the Saman Dance which provide positive moral values in the life of Indonesian people. The purpose of this paper is to clearly explain the values and characteristics contained in the Saman Dance which are useful as the foundation of life for the

\footnotetext{
${ }^{3}$ Putriani, et all. Pertunjukan Saman di Blangkejeren Aceh, Universitas Sumatera Utara: Laporan Penelitian, 2012.

${ }^{4}$ Saripaini \& Maimoenah. Karakteristik Spiritual dalam Tradisi Robo-Robo Pada Masyarakat Kecamatan Sungai Kakap Kalimantan Barat, Jurnal Studi Agama dan Masyarakat 17 (2), p:96-106. Dimensia.

${ }^{5}$ Grendi, Hendrastomo. Nasionalisme VS Globalisasi; Hilangnya Semangat Kebangsaan, Jurnal
}

Al Qalam: Jurnal Ilmiah Keagamaan dan Kemasyarakatan Vol. 16, No. 1 Januari - Juni 2022 
Hardi Alunaza, Mentari : Characteristics Of Spiritual and Social Values in Saman Dance Culture In Gayo Community

wider community. Thus, this paper will be divided into several important sections in explaining the spiritual and social characteristics of the Saman Dance. The first is in the field of education. The second is in the socio-cultural field. The third is in the religious aspect.

\section{National Identity Concept}

National identity in the context of the Indonesian nation has an explanation in the form of cultural values that grow and develop in various lives which are part of the unity of Indonesia which becomes a national culture with reference to Pancasila and Bhineka Tunggal Ika as the basis of the development process. So it can be said that the national identity of the Indonesian nation Pancasila whose actualization can be seen in the arrangement of cultural values that are reflected in the national identity and is constantly evolving for the sake of progress.

Indonesia's national identity refers to a pluralistic nation that is reflected in the plurality of ethnic groups, religions, cultures, and languages. Culture is one of the elements of national identity which is a benchmark for ethical and moral values, both those that are ideal or should be as well as those that are operational and actual in everyday life. Like the many cultures that exist in Indonesia that form a national identity as a nation that is rich in pluralism.

Koento Wibosono explained that national identity is a manifestation of cultural values that grow and develop in aspects of a nation's life with characteristics that are different from other nations. National identity is an identity inherent in a group based on the similarities of culture, religion, language, desires, and ideals. Related to this research, the author sees that the national identity of a nation is reflected in the cultural values possessed by a country. The cultural dimension is one element in the formation of national identity. The national identity of the Indonesian nation, in this case, is reflected in the cultural dimension that Indonesia has, namely the Saman Gayo Dance.

\section{RESEARCH METHODS}

This research on the characteristics of spiritual and social values in the Saman Dance culture in the Gayo community is a descriptive study with a qualitative approach. The data analysis technique in this paper refers to the data analysis technique of Miles and Huberman with three stages, namely data collection, data processing, and drawing conclusions. The data collection technique in this paper is to use data collection methods that are literature study to more accurately research from a scientific perspective ${ }^{6}$. This method is carried out with the topic of the problem raised through research on books, writings, articles that can support the topic raised.

${ }^{6}$ Sugiyono, Metode Penelitian Kualitatif Kuantitatif R \& B, Bandung: Alpabeta.

Al Qalam: Jurnal Ilmiah Keagamaan dan Kemasyarakatan Vol. 16, No. 1

Januari - Juni 2022 
Hardi Alunaza, Mentari : Characteristics Of Spiritual and Social Values in Saman Dance Culture In Gayo Community

\section{RESULTS AND DISCUSSION}

\section{The Function of Gayo Saman Dance and Strengthening Local Identity}

Saman dance is one of the media to convey da'wah, this dance is a means of delivering messages which means education, religion, manners, heroism, cohesiveness, and togetherness. The Saman dance poetry itself is used in Arabic and Acehnese. Before the Saman Dance, which is the opening, a traditional youth will appear to represent the local community to deliver advice which also contains Islamic messages and da'wah advice. The songs and lyrics are revealed simultaneously and continuously, the players consist of young men wearing traditional clothes. The presentation of the dance can also be staged, contested between the guest group and two groups. The assessment is based on the ability of each group to follow the movements, dances and songs (poems) presented by the opposing party.

The function of the Saman Dance is entertainment and beauty because in the movement of the Saman Dance, beauty and aesthetics are described that are able to amaze anyone who sees it. This is because each lyric sounds distinctively rhythmic, coupled with the movements that have many variations. Another thing that makes Saman Dance beautiful is because of the alternating fast movements, at first glance it looks as if they can collide, but that doesn't happen because every dancer puts himself in the right position.

Second, the identity of the Gayo Lues community, the Saman is believed to be their identity. With Saman Dance as a culture, the values contained in the Saman itself will always be lived by the people, both Islamic religious values and traditional values with Islamic nuances. Third, law enforcement. The Saman dance has values that reflect law enforcement, especially at the people's party Saman, in that Saman it is clear that law enforcement is enforced. This law enforcement effort is illustrated when a traditional leader from the host conveys advice called keketar. The meaning is that if there is an error, it will be subject to sanctions based on the level of violation. Fourth, da'wah and information media, Saman functions as a medium for delivering da'wah messages and information. Fifth, as a means of unifying the Gayo Lues community. Sixth, Saman Dance as a means of cultural preservation. And seventh, the implementation of the Saman Dance can be used as a place to sell (market opportunities).

However, it is ironic that most Indonesians know that Saman comes from Aceh in general, even though the Saman Dance is from the Gayo community in Aceh. What is of concern is why this Saman Dance has become a brand of the Acehnese community without the involvement of the Gayo community as the original owner of the Saman Dance itself. The thing that must be considered is the dominance of the Regional Government over the original Gayo culture, namely Saman. So far, people outside Aceh only see that the Saman Dance is the identity 
Hardi Alunaza, Mentari : Characteristics Of Spiritual and Social Values in Saman Dance Culture In Gayo Community

of the Acehnese people as a single entity. Whereas the Saman Dance is the original property of the Gayo people who live in Aceh as stated in the UNESCO recognition. In this case, the local government is expected not to make historical cultural claims and justifications, especially to the Gayo Saman Dance. As a result of a lack of understanding, the Saman Dance now appears and is present in the community, but it is different and very far from the authenticity of the original Saman Dance. On the one hand, the Regional Government can be proud of the emergence of the name Saman Dance as an Acehnese entity. But on the other hand, the claim of culture by the Regional Government is considered to violate the spirit of regional autonomy as one of the advantages in the local cultural wisdom of the Gayo community.

At present, the Saman Dance in the Republic of Indonesia has many versions. This happened; the original Saman Dance from Gayo Lues was developed by Sheikhs who moved cities or regions so that there were many new versions of Saman Dance. The emergence of this new version of Saman Dance appears slowly, from changes in movements, singing, costumes and the number of dancers. This Saman Dance is actually only played by men, but over time, this Saman Dance is played by women too, with different songs, and different costumes. This arises because the Saman Dance has been developed and has been disseminated through religious events or events that are not religious holidays.

The actualization of local cultural identity in the Saman Dance shows that the Saman Dance is not just entertainment, but also as a demonstration of the local identity of the Gayo community. The Saman Gayo dance shows the identity of the Indonesian people who have a culture that must be preserved and acknowledged for its existence. On the other hand, a pluralist Indonesian society with all its local diversity is seen as capable of producing a very beautiful cultural vehicle. The local cultural wisdom that is owned can actually emit a positive light to other nations. Preserving local culture, the substance is to strengthen the foundation of local culture so that it can become a pillar and part of identity at the national level which will eventually become a positive icon in the eyes of the international community. Saman dance is not only a form of movement that contains beauty, but also contains a good message. The beauty can be seen from the patterns of singing and movement. The elements of Islamic teachings contained in the Saman Dance refer to the customs of the Gayo community.

In its development this art is used as a medium of da'wah for the development of Islam. As a medium for the development of the Islamic religion, we can still feel it in its poems, especially in the initial steps, always starting with greetings. Saman dance was born around the XIV century. But if the dance is used as a tool for spreading Islam, then the dance has existed

Al Qalam: Jurnal Ilmiah Keagamaan dan Kemasyarakatan Vol. 16, No. 1 Januari - Juni 2022 
Hardi Alunaza, Mentari : Characteristics Of Spiritual and Social Values in Saman Dance Culture In Gayo Community

before Islam entered the Gayo Land. Until now, no literature has been found about Sheikh Saman who is believed to be the developer of the Saman dance.

Saman dance can be classified as entertainment or performance dance, because dance performances are not tied to a particular time, event or ceremony. Saman dance can be performed on any occasion that is crowded and joyous, such as birthday parties, weddings, or other celebratory celebrations. As for the place, the Saman Dance is usually performed at home, in the field, and some use the stage. The Saman Gayo dance is usually performed guided by a leader who is usually called the Sheikh. Saman dancers and Sheikhs must be able to work well together in order to create a compact and harmonious movement. Saman dance is used as a propaganda medium. Before Saman begins, traditional leaders appear to represent the local community.

\section{Saman Gayo Dance Philosophy}

Appreciation through the meaning of the Saman Dance movement is done by making a mumbling sound or in the Gayo language it is called Rengum. It aims to give enthusiasm to the dancers. Then proceed by reciting the sentence of monotheism and in a different rhythm from the first phrase. This appreciation aims to understand religious affairs, especially those related to monotheism. However, there are no special demands in the appreciation of the Saman Dance movement. The movement in the Saman Dance has its own meaning and function, which is the reason that every dancer must concentrate and be aware.

The Saman dance which comes from Gayo has a very broad meaning, especially when it is associated with a scholar like Syekh Saman, because in Saman there is the meaning of Saman as a medium of da'wah that reflects the life of the Gayo Lues community who are Muslim ${ }^{7}$. The da'wah meant in the philosophy of the Saman Dance is a da'wah that is fully Islamic in nuance, including the singing material as a whole with Islamic breath. The philosophy of the dominant Saman Dance is contained in very principled rules and must be adhered to, so that it can be a harmonic and a balancer in living life.

\section{Saman Dance Movement and Dancers}

The Saman Gayo dance uses two elements of motion which are the basic elements in the Saman Dance, namely clapping and clapping the chest. When spreading Islam, Sheikh Saman studied ancient Malay dances, and then brought them back through motion accompanied by Islamic da'wah poems to facilitate his da'wah. In the present context, this religious ritual dance is still used as a medium to convey da'wah messages through performances.

${ }^{7}$ Masyitah, Ultari. Educational Values in the Saman Dance in Blangkejeren Gayo Lues. Jurnal Catharsis 8 (4). 2019. P: 383-391.

Al Qalam: Jurnal Ilmiah Keagamaan dan Kemasyarakatan Vol. 16, No. 1 Januari - Juni 2022 
Hardi Alunaza, Mentari : Characteristics Of Spiritual and Social Values in Saman Dance Culture In Gayo Community

The Saman dance is one of the dances that are quite unique, because it only shows clapping and other movements, such as shaking, kirep, lingang, surang-saring (all of these movements are in Gayo language. In addition, there are two lines of people singing while clapping and all the dancers of the Saman Dance must dance in harmony. In the Saman Dance usually, the tempo will be faster and faster so that the Saman Dance is interesting. In general, the Saman Dance is played by dozens or dozens of men, but the number must be odd. However, in subsequent developments, this dance is also played by women. This dance is danced by less than 10 people, with details of 8 dancers and 2 people as signaling while singing. However, developments in the modern era require that a dance will be livelier if danced by a greater number of dancers. This is where the role of the Sheikh is; he must arrange the movements and sing the Saman Dance poems.

The thing that is of concern in the Saman Gayo Dance is that the Saman Dance dancers are male and it is not justified at all for female dancers because by nature and nature it is impossible for women to play Saman Dance by hitting the chest hard to make a sound like the sound of a drum. It is also not permissible for women to dance the Saman in their native area, considering that the dance is gentle at first but at other times it must move quickly, hitting the chest and thighs hard to bring out the hard ones. The number of dancers in the Saman Dance always has an odd count, starting from eleven, thirteen, until the final count is 21 .

The dance position is sitting on your knees and lined up in a row with the intention of meeting each other's shoulders. If it is performed in a position other than sitting and kneeling, then it is no longer called the Saman Dance. The costumes used must cover the genitals such as clothes with pockets and embroidered specifically for the dancers. The motif used is filigree which is equipped with suel naru and pawak. Saman dancers, at the same time combining elements of dance and sound art, are not allowed to be controlled by people outside the line. The combination of elements of dance and sound in saman is flexible, meaning that at certain times both can be balanced, but it can also be that the art of sound is more dominant and vice versa. The sound of music is produced by clapping hands. Saman doesn't use a musical instrument, so he doesn't need a recording device to voice his singing. The main movement is to move the hands from the thighs to the chest parallel or crossed, clapping, shaking or nodding the head, moving the body forward, backward, rotating sideways alternately, and shaking.

\section{The Social Meaning of Gayo Saman Dance}

The Saman dance as an entertainment dance is one among humanistic discipline. Saman is made to celebrate a ceremonial event during a certain occasion to offer a festive and fun atmosphere. As an entertainment, Saman is enjoyed with joy and aesthetic 
Hardi Alunaza, Mentari : Characteristics Of Spiritual and Social Values in Saman Dance Culture In Gayo Community

pleasure. The enjoyment that folks have for enjoying the dance comes from the connection between the dancer and therefore the dance itself. Whereas, the aesthetic pleasure comes when someone enjoys the performing art and features a good feeling of it. Moreover, the pleasure can comes subjectively and senselessly from the taste and therefore the aesthetic value the dance has. And, this sense can give benefits and values of what called as a goodadn what called as a beauty consistent with the principles and traditions of the Gayo people. The feeling of joy for enjoying the satisfying dance performance makes the people of Gayo put Saman as an entertainment that contains the values of excellent and wonder. As a beauty, Saman gives a meaning through the poems because the music component of the dance and therefore the meaningful pattern of motions, in order that the Saman dance isn't only a standard entertainment. The values of excellent and wonder in Saman make it an integral a part of life. For the Gayo people, Saman is usually performed in many events they create. People come freely and happily to observe the Saman performance on the events. If someone knows Beseuman event is being held in one village, they're going to begin to celebrate the event in droves. The absence of other entertainments in Gayo Lues also makes Saman as an expected one. Nowadays, the people of Gayo Lues have the development of living; traditional performing art remains the prima donna. It's also because the values of excellent and wonder of Saman make it not a general entertainment for them.

As an entertainment, Saman is typically performed in celebrating the 2 days two nights event of the Islamic holidays (as for Saman Jalu), the birth commemoration of Prophet Muhammad SAW, wedding ceremonies, circumcision festivals or the events of naming baby and other national important events (as for Saman Bepukes). Moreover, harvesting paddy as a crucial event within the village is additionally celebrated by the performance of Saman because the expression of joy due to the increased production of rice. Thus, the village groups will invite others to bop Saman together (as for Bejamu Saman).

The Saman competition is additionally one among entertainments for the society besides the opposite sorts of Saman. This competition is additionally called the Saman Festival that's performed on the event of the Anniversary of Blangkejeren or the events of the Ministry of Tourism. The Saman competition has caused some changes in performing Saman as within the time of performing it, the movements, the poems, the ground patterns, the judges, and even the dancers (nowadays Saman isn't only performed by men, but also performed by women). These changes aren't matters for the people of Gayo Lues as they're very tolerated with the creativity that the performers have made in performing Saman. However, the gender in performing Saman remains a matter for them as they still 
Hardi Alunaza, Mentari : Characteristics Of Spiritual and Social Values in Saman Dance Culture In Gayo Community

believe that the dancers must be all men. Even, these changes make Saman become more popular although the way in performing it's sometimes different from one group to a different. It also means the changes contribute in creating the variations of performing Saman together characteristic of traditional arts of Gayo Lues.

Saman isn't only an entertainment. As another function, it's an integration of the people of Gavo, even the people of Aceh. This integration is extremely important for the unity of a general understanding because it creates a custom of 1 society. Through Saman, the mixing also can create a contribution of the unity of the Aceh people generally and therefore the Gayo people particularly. Consistent with Merriam, one among the functions of music is as a way of society gathering. The sorts of music that are played usually invite the members of the society to interact in activities and work together cooperatively. Through music, its members are drawn to enjoy the event together, and remind them of the importance of their unity.

The concept delineation of Merriam exactly describes one among the functions of Saman Gayo. Among the functions of Saman, the author considers the most function of it which is to offer a contribution to the mixing of society. The Gayo people contain some ethnic groups, races and social groups. They categorize themselves into groups thanks to their similarities. Because the result, there's always a social conflict among them once they do their activities, including arts. However, on the opposite hand, they also realize the harm which will happen because the results of the social conflict. Therefore, they have an integration that's supported the social spirits what so very familiar in Indonesia called beauty in diversity.

Saman together example of the cultural ethnic arts is in a position to contribute in creating the mixing of the Aceh folks that is heterogeneous. The contribution of Saman to social integration closely relates to the ethnicity and therefore the flexibility of the Gayo people. Moreover, it also can provide a distinctive cultural identity of the Gayo people among the varied ethnic groups of Aceh. And if this integration happens during a wider scope, then togetherness and mutual needs of citizenry will make them reflect themselves as a social being during this world.

Saman as a celebration of spiritual activities of the Gayo people, which is usually performed within the Islamic holidays, may be a regular entertainment that automatically becomes a continuity of the Gayo culture. Consciously or unconsciously, this activity has been passed down through generations so far. This also makes the young generation to exchange the old one and obtain involved in performing Bejamu Saman. The 
Hardi Alunaza, Mentari : Characteristics Of Spiritual and Social Values in Saman Dance Culture In Gayo Community

old generation that also gets involved as mentors passed down not only the art of Saman, but also the principles and norms of it.

In Bejamu Saman, the Saman dance that's performed during a certain competition is different from the one among the Saman Festival. It becomes a cultural revitalization and takes a neighborhood in efforts to preserve the Gayo culture. The Saman competition together of the efforts to preserve and continue the Gayo culture may be a competition that gives a prize for the winner. The competition can create a replacement creativity in performing Saman and somewhat has showed the values of the Gayo traditions in new improvements and creativities. The growing of the Saman dance groups in one village has made them not only practice it for common events, but also push its members to practice the varied sorts of Saman for the religious and national events. People initiatively contribute to form the event festive and successful.

\section{The Value of Education and Unity in Saman Gayo Dance}

Saman Gayo dance is closely related to the values of education and unity. So don't be surprised if this dance is a concern and liked by many people not only in Indonesia but also around the world. Because this Saman Dance is closely related to the teachings of goodness, wisdom, nobility, and upholds togetherness and the value of unity. Also, Saman is giving meaning of educational massage for the young people to keep the local tradition from other's people distractions ${ }^{8}$. As Islam teaches its adherents to live regularly in accordance with the scope and teachings of Islam in order to establish a good relationship between humans and humans and humans with the Creator9.

The poems and songs contained in the Saman Gayo Dance always teach humans to unite, not at odds, and compact. The same dancers also teach those who are present to watch them to remain and continue to cover their genitals. As Allah commands in the Qur'an Surah Al-A'raaf that humans are commanded to wear the best clothes and cover their genitals. On the other hand, the meaning in education of the Saman Dance is to teach humans to continue to think positively in accordance with the teachings of the Qur'an ${ }^{10}$. Because covering the genitals is a good behavior that is ruled in Islam ${ }^{11}$. Not only that, the Saman Gayo Dance also teaches that humans must cover

\footnotetext{
${ }^{8}$ Naelil, Majiyah. Et all., Analisis Nilai Spiritual dalam Pembentukan Karakter Pada Buku Cerita Rakyat Karya Widodarsono, Jurnal Indonesian Value and Character Education 2 (1), 2019. P: 11-18.

9 Ainah, Noor et all., Aktivitas Beragama Mahasiswa FKIP Universitas Lambung Mangkurat, Jurnal Qalam, 2020. P:78-94

${ }^{10}$ Hardiyanti, Rahmah, Konsep Berpikir Positif dalam Meningkatkan Kemampuan Self Healing, Jurnal Qalam, 2021.p: 118-126.

${ }^{11}$ Tenny, Sujatnika, Nilai-Nilai Karakter dalam Membangun Preadaban Manusia, Jurnal Tsaqofa, 2017. P: $134-145$
}

Al Qalam: Jurnal Ilmiah Keagamaan dan Kemasyarakatan Vol. 16, No. 1 Januari - Juni 2022 
Hardi Alunaza, Mentari : Characteristics Of Spiritual and Social Values in Saman Dance Culture In Gayo Community

themselves from gaps and acts of destruction on earth. Through Saman Gayo Dance, the wider community is also taught not only to think about the life of the world, but also to think about the hereafter. As contained in the letter Al-Qasas: 77.

\section{CONCLUSION}

Saman Gayo dance plays a major role in increasing the value of spiritual characteristics and also moral values for the Gayo community in Bener Meriah Regency. This Saman dance teaches good values ranging from values in the field of education, unity and integrity, friendship, and also socio-cultural values in the form of efforts to maintain and preserve the values that have been owned by the Gayo community for a long time. Not only that, the Saman Gayo Dance also functions as a forum to strengthen the nation's national identity. One of the goals of this Saman Dance is to foster an attitude of nationalism and a sense of love for the homeland.

\section{SUGGESTION}

Writer suggest to all young people to learn more about local culture as a good way in maintaining national identity. The local culture is still giving good contribution for our nation development and national identity itself.

\section{REFERENCES}

Ainah, Noor. et all., Aktivitas Beragama Mahasiswa FKIP Universitas Lambung Mangkurat, Jurnal Qalam, 2020. P:78-94

Alunaza, Hardi. Analisa Diplomasi Budaya Indonesia Melalui Tari Saman Gayo dalam Mengukuhkan Identitas Nasional Bangsa, Jurnal Hubungan Internasional, 2015. P: 88-96.

Hendrastomo, Grendi. Nasionalisme VS Globalisasi; Hilangnya Semangat Kebangsaan, Jurnal Dimensia Vol (1).

Majiyah, Naelil,. Et all., Analisis Nilai Spiritual dalam Pembentukan Karakter Pada Buku Cerita Rakyat Karya, Indonesian Value and Character Education Journal, 2019. P: 11-18

Putriani, et all. Pertunjukan Saman di Blangkejeren Aceh, Universitas Sumatera Utara: Laporan Penelitian, 2012.

Rahmah, Hardiyanti. Konsep Berpikir Positif dalam Meningkatkan Kemampuan Self Healing, Jurnal Qalam, 2021.p: 118-126.

Saripaini \& Maimoenah. Karakteristik Spiritual dalam Tradisi Robo-Robo Pada Masyarakat Kecamatan Sungai Kakap Kalimantan Barat, Jurnal Studi Agama dan Masyarakat 17 (2), 2021 p:96-106.

Sugiyono, Metode Penelitian Kualitatif Kuantitatif R \& B, Bandung: Alpabeta.

Sujatnika, Tenny. Nilai-Nilai Karakter dalam Membangun Preadaban Manusia, Jurnal Tsaqofa, 2017. P: $134-145$

Al Qalam: Jurnal Ilmiah Keagamaan dan Kemasyarakatan Vol. 16, No. 1

Januari - Juni 2022 
Hardi Alunaza, Mentari : Characteristics Of Spiritual and Social Values in Saman Dance Culture In Gayo Community

Ultari, Masyitah. Educational Values in the Saman Dance in Blangkejeren Gayo Lues. Jurnal Catharsis 8 (4). 2019. P: 383-391.

Widodarsono, Jurnal Indonesian Value and Character Education 2 (1), 2019. P: 11-18.

Yusnizal, Henywati. Tari Saman Pada Masyarakat Aceh; Identitas dan Akutalisasi, Laporan Disertasi Doktoral. Universitas Negeri Medan.

Al Qalam: Jurnal Ilmiah Keagamaan dan Kemasyarakatan Vol. 16, No. 1 Januari - Juni 2022 